\title{
Olive oil quality vary with cultivars and agro-climatic conditions
}

\author{
Azmat Ali Awan ${ }^{1}$, Mohammad Ilyas ${ }^{2 *}$, Nasim Ahmad ${ }^{3}$, Manzoor \\ Ahmad $^{4}$, Aasia Ramzan ${ }^{1}$, Rafi Ullah ${ }^{5}$, Nadia Bostan ${ }^{2}$ Jawad Ali $^{5}$ \\ and Mazhar $\mathrm{Ali}^{2}$ \\ 1. Pakistan Oilseed Development Board Islamabad -Pakistan \\ 2. Agriculture Research Institute Mingora Swat-Pakistan \\ 3. Agriculture Research System Khyber Pakhtunkhwa-Pakistan \\ 4. Department of Agriculture, Bacha Khan University Charsadda-Pakistan \\ 5. Department of Agriculture University of Swabi-Pakistan \\ *Corresponding author's email: Ilyas_swati88@yahoo.com \\ Citation \\ Azmat Ali Awan, Mohammad Ilyas, Nasim Ahmad, Manzoor Ahmad, Aasia Ramzan, Rafi Ullah, Nadia \\ Bostan, Jawad Ali, and Mazhar Ali. Olive oil quality vary with cultivars and agro- climatic conditions. Pure \\ and Applied Biology. Vol. 9, Issue 4, pp2571-2576. http://dx.doi.org/10.19045/bspab.2020.90273
}

\begin{tabular}{llll}
\hline Received: 25/04/2020 & Revised: 01/07/2020 & Accepted: 04/07/2020 & Online First: 06/08/2020
\end{tabular}

\section{Abstract}

Three olive cultivars Pengalino, Coratina and Leccino were grown at various ecological zones of Pakistan i.e. Olive Model Farm (OMF), Mardan and Barani Agriculture Research Institute (BARI), Chakwal to assess the oil quality during two consecutive years, 2008-09 and 2009-2010. Means for peroxide and acid value of olive oil were significantly influenced by cultivars and locations. The cultivar Coratina had the highest peroxide (18.50 milli eq/kg) and acid value (2.65\%). By contrast, the least peroxide value $(12.75 \mathrm{milli} \mathrm{eq} / \mathrm{kg})$ and acid value $(2.49 \%)$ was recorded in oil extracted from cultivars Pengalino and Leccino respectively. The interaction of olive cultivars and location of production revealed significant influence on both the two parameters under study. The peroxide value which was lower in oil of cultivars Leccino and Coratina (7.53 and 9.80 milli eq/kg respectively) but increased to 23.11 and $27.21 \mathrm{milli}$ eq $/ \mathrm{kg}$ in oil obtained from Chakwal location. While the peroxide value of cultivar Pendallino was not affected significantly. The acid value of olive oil was the least $(0.85 \%)$ in cultivar Leccino and the highest $(2.89 \%)$ in Pengalino at Sangbhatti farm.

Keywords: Cultivars; Locations; Oil quality; Olive

\section{Introduction}

Olive fruit is a rich source of nutrition and its therapeutic properties [1]. It reduces LDL and increase HDL because it contain sufficient amount of C18:1cis [2]. It also contains high amounts of phenol and Vitamin E, which decline the degeneration of human body cells $[3,4]$. Olive oil greatly stabile of against oxidation during storage is attributed to the presence of polyphenols [5]. Total edible requirement of Pakistan is $3.53 \mathrm{~m}$ tons out of which our local production is 0.87 million tons [6] and import 2.67 million tons, with the cost of 2.50 billion $\$$ annually [7]. Several other oil producing crops i.e, soybean, canola and sunflower, etc have been introduced, but 
it could not be substitute of traditional crops [8]. Quality oil depends on the fatty acids compositions, phenolic compounds, peroxide value and acidity and may be influenced by different varieties [9] and location of the production [10] due to changes in elevation [11] and environmental factors during plant growth and ripening [12]. The olive oil is a rich source of phenolic compounds such as hydroxytyrosol, 3, 4DHPEA), tyrosol and simple phenolic acids. The phenolic compounds content is an important quality attribute of olive oils because it contributes to oil flavor and causes resistance to oxidation, bitterness and pungency of olive oil taste $[13,14]$ thus its stability [15]. The peroxide value is a measure of primary oxidation and is reported to be 10.64 meq/ kg initially [16]. The quality and stability of olive oil is determined by lipid oxidation, that is influence of multiple factors, such as light, temperature, enzymes, and metals over maturity [3], chilling exposure [17] climatic conditions [10]. Thus, the study was initiated to assess the best oil quality of olive varieties grown at various locations varying in altitude, temperature, rainfall and humidity.

\section{Materials and methods}

For oil quality analysis the oil obtained from the fruits of different varieties from both locations and extraction was done through pressing method and analysis was done at PCSIR, Peshawar. Two years data were combinally analyzed according to the procedure appropriate for by CR design. Mean were compared when $F$ test were found significant [18]. The oil quality was evaluated according to the procedures described in Association of Official and Analytical Chemistry [19].

\section{Determination of peroxide value (POV)}

Peroxide value was determined by the method described through following method. Oil sample (0.5 g) was taken into a $250 \mathrm{~mL}$ flask and $30 \mathrm{~mL}$ of acetic acid and chloroform (3:2) solution was then added. Saturated potassium iodide $(0.5 \mathrm{~mL})$ was added and the solution was shaken for 1 minute. Add distilled water $(30 \mathrm{~mL})$ to the solution and was titrated against $0.1 \mathrm{~N}$ Sodium thiosulfate till the yellow color was disappearing. $2 \mathrm{~mL}$ of starch solution was added to the sample and titration continued till the color was discharged. A blank without sample was also titrated against $0.1 \mathrm{~N}$ sodium thiosulfate. The blank titration was not allowed to exceed from $0.1 \mathrm{~mL}$ of the $0.1 \mathrm{~N}$ Sodium thiosulfate solution.

$\mathrm{S}=$ Sample for titration

$\mathrm{B}=$ Blank

$\mathrm{N}=$ Normality of sodium thiosulfate

$$
P O V=\frac{(\mathrm{S}-\mathrm{B}) \times \mathrm{N} \times 100}{\mathrm{Wt} \text { of sample }(\mathrm{g})}
$$

\section{Results and discussion \\ Per Oxide (milli eq/kg)}

The Peroxide value of the oil was significantly affected by varieties, site of location and their interaction $(\mathrm{C} \times \mathrm{L})$. The highest mean Peroxide value (18.50 milli eq $/ \mathrm{kg}$ ) was recorded in oil of cultivar Coratina, followed by Leccino (15.32 milli eq $/ \mathrm{kg}$ ) whereas oil of cultivar Pendallino had the least Peroxide (12.72 milli eq $/ \mathrm{kg}$ ). The mean Peroxide value was higher $(20.81 \mathrm{milli} \mathrm{eq} / \mathrm{kg})$ at Chakwal than 10.21 milli eq $/ \mathrm{kg}$ recorded for Sangbhatti (Table-1). In $\mathrm{C} \times \mathrm{L}$ interaction, the highest per oxide value (27.21 milli eq/ $/ \mathrm{kg}$ ) was recorded for oil of cultivar Coratina al location Chakwal, while the least peroxide value $(7.53$ milli eq $\mathrm{kg}^{-1}$ ) in oil extracted from olive cultivar Leccino grown at Sangbhatti 
location (Fig.1). The Per Oxide value (POV) of the olive oils is below 20 meq of oxygen $/ \mathrm{kg}$ of oil and accepted as the quality virgin olive oil [20]. These per oxide value of olive oil of cultivars is determined by genotype $\mathrm{x}$ environment interaction [21] and fruits quality as influenced by mechanical injuries due to insects and pests, improper systems of harvesting, transport and storage [3]. At Chakwal the POV value exceeded from the limit may be attributed to the environmental conditions of that location. The per oxide values of the oil observed during the course study are below the standard limits for extra virgin olive oils (EEC Regulations) except at Chakwal location.

\section{Acid value of olive oil}

The mean acid value of the olive oil was not significantly different among the olive cultivars under study but was significantly higher $(2.95 \%)$ at in olive oil for location Chakwal as compared to $2.15 \%$ observed for olive oil obtained at Sangbhatti (Table 1). In $\mathrm{C} \times \mathrm{L}$ interaction, the highest acid value $(4.14 \%)$ was recorded for oil of cultivar Leccino grown at location Chakwal that declined to the least acid value $(0.85 \%)$ in oil extracted from the same cultivar, grown at Sangbhatti location. By contrast the acid value of the oil of cultivar Pendallino (2.89\%) decreased significantly to $2.14 \%$, when the same cultivar was grown at Chakwal location. The acid value of oil from cultivar Coratina was not significantly affected by the two locations (Fig.2). Acid value influences the quality, typically the shelf-life parameters of olive oil. Acid value can be affected by different variables like temperature, altitude, latitude, soil texture and composition, method of extraction and storage [22]. However some of the published data showed that year, location, latitude, longitude, elevation do not show significant correlations with individual quality parameters and when data from different varieties were considered [23]. In case of our studies all the above variables more or less are responsible for the variation in acid values of different varieties.

Table 1. The interaction of olive cultivars and production location on the peroxide and acid value of olive oil

\begin{tabular}{|c|c|c|}
\hline Cultivars & Peroxide Value & Acid Value \\
\hline Leccino & 15.32 & 2.49 \\
\hline Pengalino & 12.72 & 2.51 \\
\hline Coratina & 18.50 & 2.65 \\
\hline LSD at & 0.902 & Ns \\
\hline \multicolumn{3}{|c|}{ Location } \\
\hline Sangbhatti & 10.22 & 2.15 \\
\hline Chakwal & 20.81 & 2.95 \\
\hline Significance & 0.736 & 0.225 \\
\hline C x L & $*$ & $*$ \\
\hline LSD at $\mathrm{P} \leq 0.05$ & 1.275 & 0.389 \\
\hline
\end{tabular}




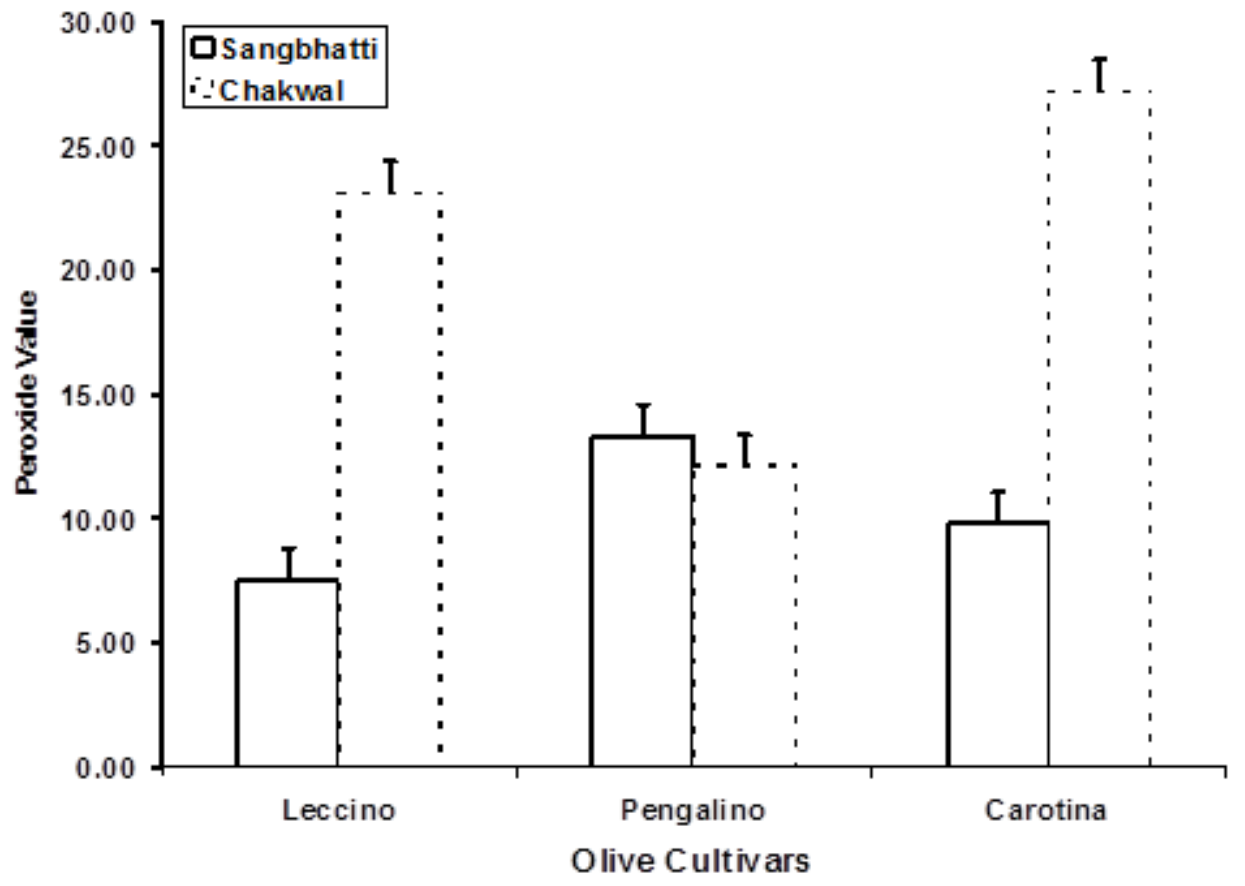

Figure 1. The interaction of olive cultivars and production location on the Peroxide Value

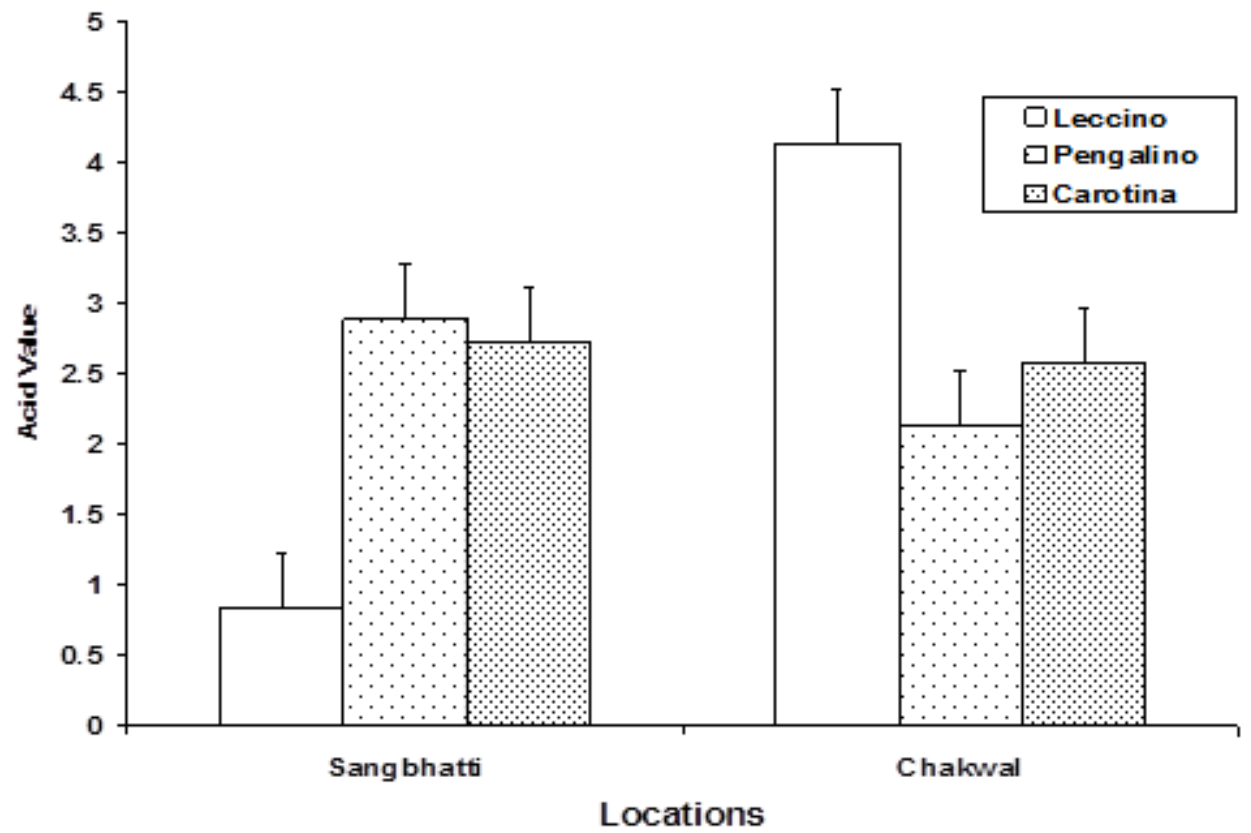

Figure 2. The interaction of olive cultivars and production location on the Acid Value 


\section{Conclusion}

It is concluded from the research that the cultivar Coratina had the highest peroxide (milli eq $/ \mathrm{kg}$ ) and acid value (\%) than rest of the cultivars. The peroxide value which was lower in oil of cultivars Leccino and Coratina increased in oil obtained from Chakwal location. The acid value of olive oil was the least in cultivar Leccino and the highest in Pengalino at Sangbhatti farm.

\section{Authors' contributions}

Conceived and designed the experiments: AA Awan, A Ramzan, Performed the experiments: AA Awan, Analyzed the data: R Ullah \& N Ahmad, Contributed materials/ analysis/ tools: $\mathrm{N}$ Bostan, Wrote the paper: M Ilyas, M Ahmad, J Ali \& M Ali.

\section{References}

1. Ashraf $\mathrm{T}$, Adriana $\mathrm{B} \&$ Francis $\mathrm{T}$ (2004). Growing olives and other tree species in marginal dry environment. International Center for Agricultural Research in the dry areas. PP 17-19. Aspects of four Syrian olive cultivars. Acta Hort 791(Part 1): 415-418.

2. Keys A, Mienotti A, Karvonen MJ, Aravanis C, Blackburn H, Buzina R, Djordjevic BS, Dontas AS, Fidanza F, Keys MH, Kromhout D, Nedeljkovic S, Punsar S, Seccareccia F \& Toshima H (1986). The diet and 15-year death rate in the seven countries study. Am J Epidemiol124: 903-915.

3. Kiritsakis, AK, Lenart EB, Willet WC \& Hernandez RJ (1998). Olive Oil: From the Tree to the Table; Food \& nutrition Press: Trumbull, Connecticut, USA.

4. Keceli T \& Robinson RK (2002). Antimicrobial activity of phenolic extracts from virgin olive oil. Milchwissenschaft 57: 436-440.
5. Argenson C (1999). Olive harvesting and storage. Oleagineux Corps Gras Lipides 6: 80-83.

6. Anonymous (2010). Annual Report. Pakistan oilseed products. PODB, pp. 233-35.

7. Khan SA, Saleem M \& Khan JI (2008). Edible oil scenario in Pakistan: 1995-2008. Quarterly Sci Vision 14: 67-72.

8. Awan AA, Zubair M, Iqbal A, Abbas SJ \& Ali N (2011). Molecular analysis of genetic distance in olive cultivars. Afr $J$ Agric Res 6(21): 4937-4940.

9. Ayton J, Mailer RJ, Robards K, Orchard B \& Vonarx M (2001). Oil concentration and composition of olives during maturation in southwestern New South Wales. Austral Expt Agric (41): 815-821.

10. Sweeney S, Butler K, Conlan D, Correll R, Jones G, McClure P \& Taylor R (2002). A survey of selected oil composition and fruit characteristics in different olive varieties across Australia. Adv Hort Sci 16(3-4): 253-258.

11. Freihat NM, Al-Shannag AK \& Elassi N (2008). Qualitative responses of 'Nabali' olive oil to harvesting time and altitudes at subhumid Mediterranean. Int J Food Properties 11(3): 561-570.

12. Tovar M, Romero P, Ramo MJ \& Motilva T (2002). Effect of crop season of the composition of virgin olive oil with protected designation of origin Les Garrigues. J Aim Oil Chem Soc 80: 423-430.

13. Kongoli (2011). Correlations of the phenolic compounds and the phenolic content in some Spanish and French olive oils"nr 56. J Agric Chem 5181-5187. 
14. Morello JR, Motilva MJ, Tovar MJ \& Romero MP (2004). Changes in commercial virgin olive oil (cv. Arbequina) during storage, with special emphasis on the phenolic fraction. Food Chem 85: 357-364.

15. Shahidi F \& Wanasundara PD (1992). Phenolic Antioxidants, Rev. Food Sci Nutr 32: 67-103.

16. Ocakoglu D, Tokatlı F, Ozen B, Korel F (2008). Distribution of simple phenols, phenolic acids and flavonoids in Turkish monovarietal extra virgin olive oils for two harvest years. Food Chem 113: 401410.

17. Osman M, Metzidakis I, Gerasopoulos D \& Kiritsakis A (1994). Qualitative Changes in Olive Oil of Fruits Collected from Trees Grown at Two Altitudes, Riv. Ital. Delle Sost Grasse 71: 187-190.

18. Jan MT, Shah P, Hollington PA, Khan MJ \& Sohail Q (2009). Agriculture Research: Design and Analysis, A Monograph. NWFP Agric Uni Pesh Pak.

19. AOAC (2000). Official Methods of Analysis of the Association of
Official Analytical Chemists International 17th Ed. Published by the Association of Official Analytical Chemists International, Suite 4002200 Wilson Boulevard, Arlington, Virginia. 22201-3301. USA.

20. Williams M, Sanchez J, Hann C \& Harwood J (1994). Lipid biosynthesis in olive cultures. $J$ Exper Bot 44: 1717-1723.

21. Ranalli A, De Mattia G, Patumi M \& Proietti P (1999). Quality of virgin olive oil as influenced by origin area. Grasasy Aceites Fase 4(50): 249-259.

22. Rondanini DP, Castro DN, Searles PS \& Rousseaux MC (2011). Fatty acid profiles of varietal virgin olive oils (Olea europaea L.) from mature orchards in warm arid valleys of Northwestern Argentina (La Rioja). Grasas Y Aceites 62(4): 399-409.

23. Ranalli A \& Angerose F (1996). Integral centrifuges for olive extraction. The qualitative characteristics of products. J Am Oil Chem Soc 73: 417-422. 